\title{
The Hybridity of South African Working-Class Literature
}

Matgorzata Drwal

South Africa is a melting pot of various ethnicities, both of European and non-European origin. As Van der Walt (2007) in his discussion on the South African working class before the I940s observes, transnational processes and circulation of ideas have always played a crucial role in shaping working-class movements, whereas South Africa's racial divisions have formed clearer divides than state borders. Therefore, the origin of working class in Southern Africa needs to be located within British imperialism and globalization in the late nineteenth century (Van der Walt, 2007, pp. 223-225). Until the Second Anglo-Boer War (1899-I902), Great Britain was successively consolidating areas of Southern Africa under its rule. The industrial revolution of the I 88 os in South Africa, following the discoveries of diamonds and gold, was, after all, part of the British imperial economy. Furthermore, the history of the South African working class also encompasses a phase of African peoples' migrations, and, at any given moment, its trajectory crosses with Afrikaner nationalism. From its conception, the Union of South Africa, established in I9IO as a self-governing British dominion embracing the former Boer republics, the Cape Colony and Natal, was a structure marked by deep cracks: dividing not only whites from non-whites, but also the Boer/Afrikaner white settler community from the other white people - the British. The working class was evolving amongst these two forces of European origin which were most often competing but also sometimes collaborating.

How to cite this book chapter:

Drwal, M. 2020. The Hybridity of South African Working-Class Literature. In: Lennon, J. and Nilsson, M. (eds.) Working-Class Literature(s): Historical and International Perspectives. Volume 2. Pp. I65-208. Stockholm: Stockholm University Press. DOI: https://doi.org/IO.I6993/bbf.g. License: CC-BY 4.०. 
From the beginning, therefore, the South African working class was by no means a homogeneous formation. Mines of the Rand attracted unskilled workers from the north of Africa: mainly male African migrant workers from South West Africa, Rhodesia, Nyasaland, and Portuguese East Africa (Mozambique). Most of white workers, in turn, were skilled or semi-skilled. A majority of these white workers were migrants commonly referred to as "Europeans," regardless of their actual place of birth. They were mostly British, but also a significant number came from Australia and New Zealand, continental Europe, and the United States (Van der Walt, 2007, p. 226). A separate group of white workers consisted of the Afrikaners, who were usually unskilled people from rural areas, so-called "poor whites" (in Afrikaans called armblankes) who were driven by poverty - a consequence of the Second Anglo-Boer War, the Depression of 1929-1932, and the drought of I932-I933 - to relocate to cities where living conditions were often not much better. These poor whites were a particularly numerous group in the I920s and I930s. By the I940s, it is estimated about ninety per cent of white underground miners were Afrikaners (Van der Walt, 2007, p. 226). Employment prospects in the city also lured white women who found jobs in the secondary industry, mainly clothing plants. The labor market was more favorable to white women than to white men who had to compete with cheaper Black workers. The social and economic situation of whites in South Africa, however, was improving throughout the I930s and the I940s. The victory of the National Party in I948, marking the official beginning of apartheid, brought the most significant change. White peoples' privileged status was legally sanctioned and most of them left the mining industry for better paid paying jobs. Consequently, the categories of "Blacks" and "working class" began to be used interchangeably.

Arriving at a definition of South African working-class literature is a multifaceted problem, not only due to the vagueness of the terms working class and literature, but also due to the complexity of South African population's structure and its dynamics over time. The question of "what makes a given text a working-class text" challenges many researchers, regardless of the local context they are examining. ${ }^{\mathrm{I}}$ The criteria include the working-class background 
of the author, the working-class experience reflected in a text, a text's popularity with a working-class public, or a text's programmatic working-class message, among others. In this last case, working-class literature is sometimes equalled with proletarian literature within the parameters of the I920s and I930s Soviet Proletkult $^{2}$ where the overall aim of a text is to help the reader realize their place in a class struggle. Furthermore, defining "literature" poses the question whether to approach only fictional, creative writings or to include press addressed to the working-class reader; theoretical studies on working class; non-fiction, e.g. biographies of working-class activists; and - specifically for Africa oral forms such as poetry and choir chants by Black workers; and forms corresponding with varying levels of the target audience's literacy. In this chapter, therefore, I will refer to all the abovementioned criteria when justifying the place of a given work within the body of South African working-class literature.

There is no comprehensive and systematic study on South African working-class literature as a separate literary phenomenon with its own dynamics. Recent literary histories acknowledge working-class creativity as part of South African literary traditions in English, Afrikaans, and other African languages. However, they usually offer cursory mentions or, at best, a brief introduction rather than any in-depth discussions of motifs, let alone of exchanges between various language traditions. ${ }^{3}$ A more comprehensive study would require a comparative approach transcending not only the boundaries of languages, but also of variously understood ethnicities (Afrikaner, British, Zulu, European, African, etc.), and skin colors (white vs. Black, or more accurately white vs. non-white). At the same time, it needs to be stressed that the history and the role of the South African working class has been given a substantial amount of attention from the political and sociological points of view. In addition, because the concept of class has always been related to race in South Africa, and throughout history the overwhelming majority of workers were Black, there exists extensive research on Black trade unionism. ${ }^{4}$ White trade unions were active in a shorter period, from the beginning of the $20^{\text {th }}$ century until about the advent of apartheid and as a topic of study did receive some attention mostly in the I 980 ond I $9905 .{ }^{5}$ 
The concept of working-class literature, in turn, tends to be used only when referring to particular case studies. Certain authors are presented as working-class authors ${ }^{6}$ or selected genres and cultural activities are studied as representative of working-class, ${ }^{7}$ such as Garment Workers Union literature, or workers' drama in Afrikaans. Instead, the concept of "urban literature" - sometimes, but not necessarily, describing the working-class experience has been extensively explored. Van Coller's (2008) discussion on representations of Afrikaner rural population's confrontation with the city in Afrikaans literature, and Van Niekerk's (20I I) overview of texts thematizing urbanization in Afrikaans, English, and Zulu, are two examples.

To avoid traps of essentialist definitions of what South African working-class literature is, in this contribution I therefore suggest a more inclusive approach encompassing a diversity of forms, languages, and traditions. I propose to conceive of South African working-class literature as a hybrid form, since, as Peter Burke (2009) observes, hybridity includes various processes, ranging from translation to a creative adjustment of a European convention to non-European contexts, which is not a simple imitation of a Western genre (2009, p. I 8). Hybrid texts are characterized by heteroglossia, to use Bakhtin's concept; there are various voices speaking within every hybrid text. Consequently, these texts are spaces of contact and exchange, which result in a subversive counter-discourse of protest literature. Yet, such discourse feeds on the culture it contests by reflecting and creatively reworking its features, adding disparate elements stemming from other traditions and ideologies. As a result, working-class literature is built upon available local forms, including South African traditions, popular genres and tropes while simultaneously incorporating foreign discourses, forms, and literary devices.

Considering its hybrid form at the intersection of discourses and genres, and its documentary character (recording the workingclass experience), I approach South African working-class literature as histoire croisée. ${ }^{8}$ This literature is an effect of rapid development and change of industrialisation and ensuing modernizing transformation of rural, traditional communities into urban ones. The histoire croisée approach is process-oriented and allows us 
to view working-class literature not as a fixed category, but as various manifestations of thought being constructed and evolving in space and time. As such, it invites looking at circumstances which facilitate or hinder certain kinds of cultural exchange. The crossing metaphor guides the researcher to investigate not only the points where the lines cross, but also to trace modifications of original forms. Moreover, Werner and Zimmermann (2006) suggest juxtaposing various scales: micro and macro. Therefore, a picture of working-class literature as part of national and transnational movements can be illuminated by case studies - the personal histories it recorded, the incidental encounters between writers, activists, and workers. In this essay, the organizing crossing metaphor of the histoire croisée refers to intersections of race, class, gender, but also to crossing of local traditions, national mythologies, transnational ideologies.

Demonstrating their hybrid nature, this contribution explores diverse forms of white and non-white working-class literature: starting from texts by white socialist theoreticians and middleclass novelists with socialist leanings to trade unionists creating drama, poetry, and songs. An overview that it offers encompasses the period from the beginning of the $20^{\text {th }}$ century until the abolishment of apartheid in I994. The forms and themes present in working-class texts written after the shift in power, the first democratic elections, and the beginning of a Black majority rule in South Africa, lie outside the scope of this essay. It needs to be underlined that this overview is by no means exhaustive but is an attempt to accentuate the most noticeable trends and features of texts about, by, or for workers of South Africa.

\section{Class and Race at the Beginning of the $20^{\text {th }}$ Century}

The deepest rift within the South African population has always been along racial lines. It was skin color that had long already shaped the identification of South African citizens, while the awareness of class was a fairly new concept emerging as the industrialization and urbanization of the country was progressing in the late $19^{\text {th }}$ century. It was also when intellectuals from Great Britain, who brought a racialized social Darwinism onto South African 
soil, undertook the first attempts at theorizing the South African working class. Within the parameters of their social Darwinian approach, they variously applied the term "race" to describe a skin color, ethnicity or even nationality, whereas with the concept of working class they referred to the whole Black population of South Africa. ${ }^{9}$

This thinking can be found for example in the writings of Olive Schreiner (I855-I920), “a British intellectual who lived only a few years in Britain, [and] a rural South African who called Britain 'home"” (Krebs, I999, p. I4I). Schreiner was the first South African-born author writing in English to become famous in Great Britain. She was a progressive activist and political commentator, influential in transnational networks of socially engaged intellectuals. ${ }^{1 \circ}$ Including her in an overview of working-class authors is debatable, though. Her background and the audience she addressed were middle-class whites and her writings did not delve into the working-class experience. Her writings, however, offer a valid point of departure because in theoretical and fictional texts alike she approached the issues of labor and the intertwining concepts of class, race, and gender - the concepts which, as she believed, cannot be discussed separately. For example, in Woman and Labour (I9II), where she theorizes the relationship between labor and gender, she focuses on the position of white middle-class women, but also elaborates on the differences between the origin and goals of male and female labor movements (Schreiner, I9I I, pp. I 22-I 26). Schreiner's approach to race and class issues can be observed in her other writings. As a vociferous critic of aggressive imperialism, capitalism, and the exploitation of the Black population by the whites in South Africa - both by the British and the Boers - Schreiner gave her protest a literary form in Trooper Peter Halket of Mashonaland (I 897). In this allegorical story, she condemned the cruelty of Cecil Rhodes's British South Africa Company towards the Ndebele and Shona on the territory which later became Rhodesia. It was in the later theoretical writings, in particular in the political pamphlet Closer Union (I909), that she most directly elucidated how the concepts of class and race are interrelated. Schreiner referred to the British and the Boers as two white races of South Africa, whereas the Black race was the 
country's working class. In this piece, almost prophetically, she warned against the depravation of Black population in the name of white man's material gain:

If, blinded by the gain of the moment, we see nothing in our dark man but a vast engine of labour; if to us he is not man, but only a tool [...] if, uninstructed in the highest forms of labour, without the rights of citizenship, his own social organisation broken up, without our having aided him to participate in our own; [...], we reduce this vast mass to the condition of a great seething, ignorant proletariat - then I would rather draw a veil over the future of this land. (Schreiner, I909, p. 50)

\section{Black Working-Class Experience: Jim Goes to Joburg}

Schreiner, voicing her protest against social inequalities and sympathy for the non-white population, was writing from an outsider perspective and so were other white socially oriented writers publishing in the first decades of the $20^{\text {th }}$ century. They tended to idealize the pastoral South Africa (Chapman, 2003, p. I42) and focus on the detrimental impact that the urbanised space had on the innocent rural Bantus. Utilizing the plot pattern often referred to as "Jim goes to Joburg," they attempted to depict the transformation of the protagonist in an industrial environment where instead of tribal bonds, he is defined by economic position. Such texts, written in English by both white and Black authors, meet criteria of working-class literature, because their aim is to reflect working-class experience and their authors, acting as observers and commentators, become historians of the people, documenting social change.

The "Jim goes to Joburg" theme presents a Black protagonist's journey from the rural space, standing for the South Africa of the past with its harmony and values defined by the tribal social organisation, ${ }^{\text {II }}$ to the modern urban space, marked by industrialization and exploitation. In these new circumstances the protagonist, exposed to the vices of the city-money, liquor, gambling, prostitutes, and violence- loses his naiveté and learns how to survive. The stories accentuate the meaninglessness of the main character's life, often pointlessly terminated by a death in a random fight. As 
Gray (I985) observes in his overview of the works representing this theme, the idealization of the rural past, "this Edenic nostalgia for a lost paradise merely underscores the inadequacies of the alternative" (I985, p. 69), the emptiness, despair and gloom of the city.

Leaven. A Black and White Story (written in I897, published in I908) by Douglas Blackburn can be listed as chronologically the first manifestation of this theme. The novel depicts the story of Bulalie, a Zulu, who as a worker is painfully confronted with the city but cannot return to an idealized rural past. Blackburn, who came to South Africa from England in I 892, as "an underpaid journalist with socialist leanings" (Chapman, 2003, p. I38), attracted by the gold rush in the Rand, was first writing satirical texts in which he attacked the corruption brought about by industrialization. Next to incisive criticism of South African colonial society as marked by a "negative coherence of greed and exploitation" (Shum, I994, p. 97), he expressed a nostalgia for a mythical South Africa, where both the Bantu and the Boers formed classless and harmonious societies. Chapman (2003) describes Bulalie as the first "credible Black figure" (2003, p. I4I) in English fiction in South Africa. Contrary to previous representations created by white authors where Black characters were flat, often comic figures, Bulalie is not a simpleton, but a character first wronged by whites who learns how to survive in the Rand, using the system to his advantage. The novel is an accusation levelled at the white government for turning the Rand mines into a just another form of British colonial exploitation. It offers an evocative portrayal of the urban environment in the "proletarian phase of colonisation" (Chapman, 2003, p. I42) and a close examination of the relationship between class and crime (Gray, I985, p. 66).

Blackburn's theoretical writings, however, poignantly demonstrate the limitations and inconsistencies of a white socialist writer's perspective on the South African class stratification at the beginning of the $20^{\text {th }}$ century. When elaborating on the idealized rural past of the Bantus, he advocated "Kaffir socialism" ${ }_{\text {I2 }}$ claiming that tribal society is "essentially socialistic" and therefore the "natives" should live in their "locations" (native reserves) where they would be safe from the degenerating influence of white 
"civilisation" with its concept of private property. According to this logic, even if Black people stayed unskilled and illiterate, they would remain unspoiled and would not develop evil qualities. Blackburn deemed this thinking (dangerously reminiscent of apartheid policy) not as segregationist but as an expression of the pastoral ideal (Chapman, 2003, p. I42). In this way, he presented the emerging Black working class as a by-product of white man's capitalism and his views echoed, in fact, the old noble savage myth with its patronizing colonial attitude towards non-whites.

Another two texts by white authors telling the "Jim goes to Joburg" story are W.C. Scully's Daniel Vananda: The Story of a Human Being (1923) and Ula Masondo (I927), a novella by William Plomer (first published in the collection I Speak of Africa). These works also offer a bleak picture of the emerging Black working class. In the first work, the author depicts the degradation of human nature due to its "essential infirmity" (Scully, I923, p. vii) which results from racial inequality. The main character Vananda, who in the city changes his name to Daniel, walks the path of degeneration - both morally and physically (he contracts a wasting lung disease) - as a mine worker, striving to survive in a hostile environment. Ula Masondo explores exploited and abused Black workers desiring the trappings of white "civilisation." In an attempt to offer a more intimate picture of an exploited Bantu, Plomer presents a nostalgia for the lost rural past as expressed in the main character's internal monologue.

The "Jim goes to Joburg" plot pattern was also explored by Black authors (although these writers were not from the working-class), who painted the working-class experience in harsh conditions. A clear example is An African Tragedy (I93I) by Zulu author Rolfes Robert Reginald Dhlomo (I90I-I97I) a mission-educated journalist and writer, representative of the elitist "New African" of the I930s and I940s. The author's hybrid identity determined his treatment of the theme: African, familiar with local, tribal tradition, yet distanced from them due to his Christian education and assimilated Calvinist norms. Writing in English, he chose to become a mediator between the world of his people and whites. An African Tragedy is a moralistic novella which presents a story of Robert Zulu, a village teacher who, in 
need of wedding money (lobola) to be paid to the family of his intended wife, sets for Johannesburg where he is confronted with the vices of the city. The author is an external observer, critical of the alcohol-drenched township culture with its marabi (a popular African jazz style at that time), which he sees as "the erosion of tradition and Christian values and norms" (Gaylard, 2005, p. 54). The story gives a good insight into segregated Johannesburg with its curfew, illiterate and corrupt Black policemen, and city gangs. The most vivid is, however, the picture of both spiritual and bodily degradation of the protagonist in the city: he contracts syphilis, and on his return to the village is punished by the community members, "God-fearing parishioners who do not accept his city ways" (Gray, I985, p. 70).

R. R. R. Dhlomo's short stories, which he published in the weekly journal Sjambok between August I929 and February I93 I, convey a less didactic and much more sympathetic social message. He focuses on the helplessness of Black workers within capitalist power structures. For example, the stories "Fateful Orders" or "The Death of Masaba" offer a sharp criticism of the corrupt ruthless system of the mines, where mine workers' lives are expendable. Garland (2005) observes that these writings were "an early form of protest writing in English" (2005, p. 56), even though Dhlomo, whose outlook was shaped by his mission education, was distrustful of political agitation.

Another example of protest writing is Mine Boy (I946) by Peter Abrahams (I9I9-20I7). This realist novel is particularly worth mentioning because it offers a more constructive and positive approach to the working-class identity formation process, even though the confrontation with the city that it presents is a painful experience. The protagonist Xuma, on his arrival in Johannesburg, is faced with the violence of urban life in a Malay Camp in the impoverished suburb of Vrededorp and ends up as a miner, part of a larger dehumanized mass, working underground in life threatening conditions. The breakthrough comes when his fellow mine workers eventually decide to take the initiative and fight for a better destiny. What particularly needs to be emphasized is that these are Black and white workers who unite for the first time for a common goal of opposing exploitation. The novel 
closes with Xuma, together with his friend, Irish foreman Paddy O'Shea, significantly nicknamed The Red One, organizing a strike in response to the death of their fellow workers in a mining accident. In this way, the text carries a straightforwardly formulated working-class message: class-conscious workers should no longer be passive victims but actively shape their lot engaging in a class struggle in which they join their efforts regardless of race. That is why Abrahams earned the name of "South Africa's First Proletarian Writer," as Michael Wade (I972) described him, even though he did not belong to the working class. Abrahams, a declared Marxist until early i940s (Masilela, 2004, p. 35), was an intellectual, Pan-Africanist and cosmopolitan in views. Influenced by the American Harlem Renaissance writers and familiar with W. E. B. Dubois's and Richard Wright's oeuvre (Jones, 20I2, p. 205), he was a renowned figure of New Black Modernity in South Africa and beyond. His work, including Mine Boy, can be viewed as positive response to change, a central premise of modernity.

The change, thematized in the plot of all "Jim goes to Joburg" texts, is triggered by the new economic situation which leads to the social, political, and cultural transformations in Black communities. The protagonist's migration to the city is mirrored by his inner journey leading to his new, modern identity. While in previously discussed texts the character's new identity was a combination of an urban Bantu and a worker, in Abrahams's exploration of the theme, Xuma becomes a class-conscious worker aware of how race and class are interrelated. Furthermore, he is instructed not only in socialism but also in humanism when The Red One suggests that he should think of himself first of all as a man, then recognize his class, and that his skin color is secondary. The interracial strike initiative makes Xuma realize what The Red One meant —his individual life matters: "Xuma smiled. Now he understood. (...) One can be a person - first. A man first and then a Black man or a white man” (Abrahams, I946, p. I82).

\section{Critical Realism and Socialist Realism}

Another take on "proletarian humanism" "s can be found in the work of Alex La Guma (I924-I985). Creating protagonists who 
are supposed to be typical of their class and environment, he consciously and expressly took the role of the "historian of the people" (Lukacs, 1963, p. 19). In a realistic and naturalistic fashion this author documented the life in working-class settlements in Cape Town, work floor relations, protest, and an awakening workingclass awareness of Blacks and people of mixed origin who in the apartheid terminology were referred to as "coloreds" ${ }^{14}$. La Guma's novels created throughout the I960s and I970s demonstrate a development in his approach: from "the exposition of the social contradictions of racial capitalism" (Mkhize, 20IO, p. 9I 5 ) towards a representation of characters actively fighting for a better future, reminiscent of those in Abrahams's Mine Boy. Mkhize (I998, p. I22) describes such figures as positive heroes that can be found in Soviet socialist realist literature and emphasizes the role of the author as an educator in class-consciousness. In terms of style, as Nkosi (I975) observes, La Guma's writing “owes much to Zola and the masculine rigour of Hemingway" (I975, p. I I2), pointing in this way to an affinity with European naturalist and American realist traditions. These "borrowed" ingredients, such as a socialist realist plot and message, and the naturalism and realism in narrative style, applied to local South African material add up to a hybrid character of this working-class literature.

As the son of Jimmy La Guma, one of the leading Black trade unionists of the Industrial and Commercial Union (ICU), Alex La Guma was raised in a home with socialist traditions. His work shows inspirations with classics: with the realism of Jack London and socialist realism of Maxim Gorky (Mkhize, I998, p. 76). Starting as a journalist interviewing the non-white communities of Cape Town, La Guma turned to realistic prose in which he hoped to truthfully portray the lives of the poor and the working-class and "at the same time to indicate the developing sense of revolt which was fermenting all the time within the communities" ("To Literary Gazette", p. 38). A Walk in the Night (1967), a story of Michael Adonis, a person of color who is unfairly dismissed from his job at sheet-metal factory by a racist foreman, belongs to the critical realist tradition, where the focus lies on the poignant portrayal of the underprivileged, with "distinct Dostoevskian undertones" (Nkosi, I975, p. 222). The novella describes dehumanizing socio-economic conditions of District Six: drinking, crime, gangs, and the helplessness of people who are victims of the 
circumstances. Chronicling details, it offers a vivid picture reminiscent of European naturalist tradition:

And in the dampness deadly life formed in decay and bacteria and mould, and in the heat and airlessness the rot appeared, too, so that things which once where whole and new withered or putrefied and the smells of their decay and putrefaction pervaded the tenements of the poor. (La Guma A Walk in the Night, I967, p. 34)

Evocative realistic descriptions of extreme poverty can be found also in And a Threefold Cord (I964). La Guma provides the reader with a minute description with the pondokkies in the Cape Flats slums on a rainy day: "it could hardly be called a street (...) a maze of cracks between the jigsaw pieces of settlement, a writhing battlefield of mud and strangling entanglements of wet and rusty barbed wire, sagging sheets of tin (...)" (p. 2I). This novel, The Stone Country (I967), and In the Fog of the Seasons' End (I972) have certain qualities of socialist realism and are La Guma's "project of forging a South African working class (proletarian) literature" (Mkhize, I998, p. 37). The characters are therefore not just representatives of the working class but also political activists striving for solidarity among the poor to oppose racial capitalism and win in a better future (compare Lukacs, I963, p. 96). In The Stone Country the protagonist is sent to prison for distributing leaflets; in In the Fog of the Seasons' End (I972) such characters as Beukes or Tekwane are depicted as self-conscious, heroic workingclass fighters, "positive heroes" and "political role models" (Mkhize, 20IO, p. 920). Beukes sacrifices his family life to take up underground resistance actions against oppressors. Tekwane undergoes a transformation according to the socialist realist novel master plot (compare Clark, 2000, p. 23). From a naïve country boy whose father died in a mine, Tekwane grows to political consciousness and becomes a working-class activist who eventually sacrifices his life and dies during a cruel interrogation by security.

\section{White Urban Experience in Afrikaans Prose and Drama: Class Stratification vs. National Unity}

Nostalgia for the idyllic rural past - which characterizes "Jim goes to Joburg" novels - is visible also in Afrikaans literature in which the encroachment of industrialization and urbanization threatens 
the freshly solidified Afrikaner national identity. This identity located its origins in the $19^{\text {th }}$ century Voortrekkers, i.e. pioneers trekking northwards of the Cape Colony in a conquest of lands outside of British authority where they could live as independent farmers. The prototypical Afrikaner - or the Boer (a Dutch word meaning a farmer) was defined by the countryside where he ruled over his farm, his family, bywoners (tenants), and non-white laborers (Van Coller, 2008, p. 29). The growing population of poor whites was a result of impoverishment of the countryside and urbanization following the Anglo-Boer War (I899-I902). Subsequent crises caused by the economic depression of I929-I933 and drought of 1933 kept fueling the process of migration to the cities. Johannesburg's suburbia of Vrededorp, Fordsburg and Brixton were typical locations where poor Afrikaners settled (Van Jaarsveld, I982, p. I79). Having no formal training in trade and industry, they competed on the labor market with Black workers, an experience many considered humiliating: "Loss of the farm was traumatic for most Afrikaners because it meant the loss of a means of production (...) it meant alienation: the fact that the independent person is forced to become a wage labourer" (Van Wyk, I990, p. I7). Therefore, the emergence of Afrikaans workingclass literature needs to be placed at the crossing of two trajectories defining two new Afrikaner identities: the first one was Afrikaner as a national identification, the second - the Afrikaner as a working-class member. A number of literary texts thematize the tension between these two competing identities: the national one rooted in the race or rather in ethnicity, which places the Afrikaner against the British (in a colonial fashion denying any political rights to non-whites); while the other one appeals to the ideal of the cross-racial worker identity.

As Van Coller (2008) observes, the Afrikaner attitude towards the city has always been sceptical, or at best ambivalent. Johannesburg has become the epitome of a treacherous place, the "Judasburg" - as it is referred to in the Vincent Pienaar novel Jo'burg, die blues en ' $n$ Ford Thunderbird [Johannesburg, the Blues and a Ford Thunderbird]. The urban space was anglicized and governed by foreign values and practices, at odds with "Afrikaner's sense of nationhood and deep adherence to a conservative Biblical theology" (Van Coller, 2008, p. 27). The key genre 
addressing the pastoral identity of the Afrikaner is the plaasroman (farm novel) where the farm is a mythical space, providing human existence with meaning, "an idyllic sanctuary, a feudal realm structured hierarchically on class and race, a mythical sphere in which heroic figures combat destiny and evil" (Van Coller, 2008, p. 32). This genre, thriving until the I950s provided a powerful narrative for Afrikaner nationalism, picturing the Afrikaner as rooted in the African soil and therefore the rightful owner of the land.

Van Coller (2008) in his overview of Afrikaans realistic prose addressing the poor whites problem (die armblanke-vraagstuk) does not use the attribute "working class" but rather "urban" and "city," stressing the contrast between the idealized farm and the negative industrialized space. Nevertheless, this literature thematizing spacial change is, in fact, concerned with the economic change affecting the social position of whites in an increasingly class-stratified society. First, in the I920s, the peri-urban novel (Van Coller, 2008, p. 35) represented by Jochem van Bruggen's Ampie trilogy (1924-1928), depicted suburban space of "white decay," and subsequently, throughout the late I920s, I930s, and I940s, the city novel portrayed protagonists who were invariably confronted with alcoholism, violence, abuse, and loose sexual behavior, which reminds the painful confrontations of Black protagonists in "Jim goes to Joburg" novels. Both traditions utilize the same central device of contrast between the city with destructive effects of modernisation: the idea of rural Bantus living harmonious lives in pre-industrial tribal Africa corresponds with the topos of an idealised rural past of the Afrikaner on his farm. For example, J. Lub's Eenvoudige Mense [Simple People] (I930) and C. M. van den Heever's Groei [Growth/Grow] (I933) thematize the degeneration of the Afrikaners living in slums - this degeneration being also moral, like in R.R.R. Dhlomo's didactic An African Tragedy where the city had a destructive impact on Black population's values and family bonds. This emphasis on the moral downfall of characters is, in both cases, due to the important role of Calvinist religion on authors' outlook. Other instances of the Afrikaans city novel showed Afrikaners as working class: Imker Hoogenhout presented in $\mathrm{Op}$ die delwerye [In the mines] (I925) 
a picture of poor mineworkers and Willem van der Berg in his novels Reisigers na nerens [Travellers to Nowhere] (I946) and Tema en variasies [Theme and variations] (I947) dealt with workers' rights, strikes, and racial relations, showing a critical attitude to the emerging class of Afrikaner industrialists, a "gang of fat cats" (Tema en variasies, I947, p. 7I).

Similarly to "Jim goes to Joburg" texts, the above-mentioned literature depicted the working class from an outsider perspective of a middle-class intellectual. In the I930s, no other perspective dominated Afrikaans drama about the poor whites' predicament. Plays focused on the dangers of city life, such as evil consequences of alcohol abuse (Drankwet [Liquor Act], I933 by E. A. Venter) or threats to young girls' moral standards (Die Stad Sodom [The City of Sodom], I93 I by F. W. Boonzaier). These plays, which addressed the question of decent behavior while depicting an economic situation, need to be interpreted within the nationalist political framework: the city is not only anglicized but also threatens the Afrikaners' racial purity.

The economic stratification of the white South African population formed a concern for the nationalist agenda proscribing the unified Afrikaner identity (Van Wyk, I990, pp. 9-10). Adopted in I93 I, the Statute of Westminster ended the Union of South Africa's dependency on Great Britain as a dominion, which provided Afrikaners with an impulse to reinforce their national identity as unique and opposed to both British and other non-European people in South Africa, such as Blacks and Asians. Even though Afrikaner nationalism was rapidly gaining support in the I930s, industrialisation and the resultant category of class as a new identification endangered the ethnicity based divisions. This threat is addressed in Hantie kom huis-toe [Hantie come home] (I933) by P. W. S. Schumann, which presents a friendly relationship between the poor white Jan and the Indian shop owner, in this way signalling that poor whites may eventually overcome racial prejudice by developing personal friendships across ethnic lines. Therefore, the dramas have a propaganda character, with characters unambiguously distancing themselves from a class cross-racial outlook: Jan openly states: "I do not believe in classes for white people" (Schumann, I933, p. 56) and other character, Aunt Grieta, 
declares: "I won't allow my child to do kaffir work" (Schumann, I933, p. 29). Another example is Die Skeidsmuur [The Dividing Wall] (I938) by A. J. Hanekom emphasizing the importance of keeping the division between jobs for whites and non-whites. The play conveys a warning against the situation in which a white domestic servant loses the old awareness of their place in social hierarchy and - as the play suggests - self-respect.

\section{Garment Workers' Union and Grassroots Proletarian Afrikaans Literature}

Afrikaans working-class literature created by authors who were working class themselves was pushed to the margins of the Afrikaans literary canon (see Willemse, I999, p. 9). N. P. Van Wyk Louw, a playwright and scholar, who wrote about the challenges of Afrikaans drama in the late I93os did not encourage poor whites to create their own literature. Instead, he proposed that the petit-bourgeois writer should emulate the poor white's subjectivity (Van Wyk Louw, 1939). Afrikaner critics dismissed writings which expressed actual popular sentiments of the working class most of all because this literature's socialist character involved a subversive inter-racial message.

The literature of the Garment Workers' Union (GWU) activists created from the I930s until about 1945 addressed the issues of class and nationality from an insider perspective, at the same time presenting a new model of urban femininity. Also, this is an Afrikaans literature which for the first time adopts the working-class/proletarian qualification and presents the Afrikaner as a class-conscious worker. The GWU literature comprises texts written by female working-class authors for a working-class public, a literature which creates a proletarian identity which is supposed to cross racial divides.

The Garment Workers' Union (Afrikaans: Klerewerkersunie) was the first professionally organized trade union consisting of predominantly Afrikaner women, recruiting from the ranks of poor whites. At the arrival in a city, it often turned out that women were better equipped to find jobs in the competitive urban market than men who were as unskilled and unprepared for the 
urban environment as Black migrants. Even though white women employed in manufacturing industry, mostly clothing and food sector, fared better than men, their situation was far from satisfactory. Due to lack of work regulations they were working long hours and received low wages.

The creation of trade unions was a response to this situation. The GWU was established in I930 on the initiative of the Lithuanian-Jewish immigrant Emil Solomon (Solly) Sachs (I900I976) who also provided the union with its ideological foundation. An admirer of Marx and Stalin, familiar with the history and organization of British trade unions, Sachs was also impressed by Soviet socialism (Verwey, I995, p. 22I). Under his leadership the union became a militant organization, fighting for the interests of semi-skilled and unskilled women workers. By 1938, female activists occupied all important positions in the GWU (Vincent, 2000, p. 63). Among the leading organizers were Anna Scheepers, Johanna and Hester Cornelius - working-class women, who conducted the union's mission to teach the newly emerging white proletariat of South Africa how to speak and fight for "bread and butter, for a happier life and brighter future" ("Our Policy", Garment Worker vol. I, no. I, Oct. I936). Just as important, they attempted to create a spirit of unity among the working masses.

The union's educational mission involved cultural events and the creation of instructive literature. From 1936, the trade union began to regularly issue its official periodical, the bilingual Klerewerker/Garment Worker. The periodical consisted of twelve through fourteen pages in English and the same number in Afrikaans running back to back. Its primary role was to inform readers about the current activities of the union, but it also published contributions on the history of trade unionism in South Africa and beyond, and literary texts, such as short stories, poems, and songs. Both language sections advertised cultural activities for the union's members, but literary texts appeared much more often in the Afrikaans section, since Afrikaans was the language of the working class, while English was associated with the clothing manufacturers (Brink, I989, p. I08). Also serialized Afrikaans translations of socialist classics appeared in the periodical, such as Upton Sinclair's novel They Call Me Carpenter 
in Hester Cornelius's translation (Hulle noem my timmerman was appearing in the issues from May/June I94I until May/June I946). Translated socialist literature provided Afrikaner workers with a broader picture of the working-class culture as an international phenomenon.

The Garment Worker $(G W)$ magazine target readership were workers from clothing factories. Most of Afrikaner workers, originating from rural regions, were conservative in their views, knew little of socialism and generally perceived it as a foreign ideology. In a changed economic situation, they did not want to shed their national identity or break links with the founding myth of the Great Trek and the pioneer self-image. To overcome reservations of the workers as regards to socialist thought, the $G W$ authors had to rely on familiar cultural motifs which they combined with depictions of urban experience that the reader could relate to in an attempt to convey a socialist message: calling workers and poor farmers to a joint struggle against capitalists.

Realistic short stories published in the periodical documented Afrikaner workers' experiences. For example, "Die baksteen" ["The Brick"] by Ida Muller describes an anonymous starving city newcomer roaming the streets in futile search of work. He is confronted with the indifference of those living in the urban environment. Next to depictions of recognizable experience within a realistic convention, some stories are overtly didactic. "Rype ondervinding" ["Mature Experience"] opens with a convincing description of the stuffy atmosphere of a factory hall and the monotonous sound of sewing machines, a mood which corresponds with the feeling of loneliness of the main character, the exemplary Anna Cloete, a country girl freshly arrived in the city. Depressed by the urban environment, she dreams of her family farm in the Bushveld which she recalls as an idealized mythical space. This nostalgia for a lost past is a feature which Garment Worker literature shares with both English "Jim goes to Joburg" texts and with Afrikaans peri-urban and city novel. But the story's most important episode is Anna's encounter with trade unionists who explain to her why she should join the union. The instructive proletarian message is communicated in an even more direct and unambiguous way than in La Guma's novels. 
Since the magazine's readership were mostly women workers, the texts reflected and shaped a new urban female identity. In a socialist realist fashion, the characters presented in texts were political role models. This didacticism was also communicated in poems, such as "Die Plig van die Vrou" ["The Duty of the Woman"] by Maggie Meyer published in the March/April I94I issue of the periodical. The piece is probably the most emblematic work presenting a new woman worker's identity as an evolution of the traditional role. The Afrikaner woman had always had an important duty towards her people: both as the fearless pioneer traversing vast spaces, supporting her husband, and as an industrial worker on strike, opposing exploiting capitalists:

The duty of the woman on earth is huge

Her love stronger than death

Together with her husband she struggles. ${ }^{\text {Is }}$

[Die vrou se plig op aard is groot,

Haar liefde sterker as die dood.

Saam met haar man die stryd te stry.] (p. 3)

The poem contains some of the recognizable Afrikaner topoi: references to the Voortrekker narrative in which women are modest and unselfish and always a steadfast supportive of their husbands. They sacrifice themselves for their family and their new country, the concepts which are interchangeable:

Over Drakensberg and plains, Through cold nights, hale and rain, She has done that for our country, And she does not look for fame for it.

[Oor Drakensberg en vlakte heen,

Deur koue nagte, hael en reen,

Dit het sy vir ons land gedoen,

En sonder om daarmee te roem.]

The mention of the Drakensberg is a direct refence to the figure of Susanna Smit who, as the legend has it, told British official Henry Cloete that she prefers to cross this mountain range barefoot rather than obey British administration. The poem is structured around the parallel between the $19^{\text {th }}$ century struggle for freedom and current struggle for decent wages. The enemy in both cases, 
though, is the same: the British, referred to as "capital," because most of the industry employing both Blacks and poor whites were British enterprises. The poem emphasizes that the most recent events of the 1932 strike are part of a longer history of resistance against oppression:

The freedom did not last long, (...)

In the factory from early till late, There you learn to hate capital.

A joint decision was taken

In 1932 they go on strike.

[Die vryheid het nie lank geduur,

(...)

In die fabriek van vroeg tot laat,

Daar leer jy kapitaal te haat.

Saam word daar 'n besluit gemaak

In I932 gaan hul op staak.]

Besides poems, songs written and performed by the Garment Workers also documented working people's social history. Songs are a powerful medium used to incite the feeling of solidarity among workers, in particular when their performance accompanies particular events. GWU songs were usually written to be sung at strikes and rallies; they commented on a situation or demanded action from the public. Since authors frequently used a familiar folk melody and added lyrics conveying a political message, these songs constitute another hybrid genre of working-class literature. The idea of providing a political text to a well-known tune, however, is not unique or new, as it had already been applied in the Little Red Songbook of the Industrial Workers of the World (I.W.W.), published in the United States for the first time in I908. Similarly, to the I.W.W. songbook, the GWU songs were parodies, marked by wit and sarcasm, designed to poke fun at employers and politicians and to boost morale during strikes. Thanks to a well-known tune, their radical message was made accessible and familiar. The value of such song rested in its belonging to a group, its performative quality and "quotability" (Furey, 200I, p. 55) which encouraged identification with the message. The Garment Workers adapted tunes of traditional Afrikaner folk songs which they and their audience associated with a familiar rural space. For 
example, the melody of "Wat maak Oom Kalie daar" ["What is Uncle Kalie Doing There"] was used to create a song to be sung at a strike at a tobacco factory in Rustenburg and appeared in the May/June I94 I issue of the periodical:

What are the scabs doing there?

(...) The strikers take a big stick

And hit the scabs on the head

$\mathrm{O}$, what are the strikers doing there.

[Wat maak die brandsiek daar?

(...) Die stakers vat'n grote stok

En slaat die brandsiek oor die kop

O, wat maak die stakers daar.] (p. 7)

Similarly, "Bobbejaan klim die berg" ["Baboon climbs the mountain"] was adapted for the union's rally on the $18^{\text {th }}$ of March I94I and published in the March/April I94I issue of Klerewerker (p. II). The lyrics refer to the current political situation and criticize the Minister of Labour Walter Madeley, and Ivan Walker, Secretary for Labour of the Union of South Africa, for unfair laws against workers. The substitution of the baboon with a politician's name produces a comic, satirical effect:

Walter Madely climbs the mountain,

$\mathrm{He}$ is our so-called friend, Walter Madeley,

$\mathrm{He}$ is now the boss over the whole working class.

Yes - Walter Madeley makes a law

To shut our mouths.

Farewell democracy now!

[Walter Madely klim die berg,

Ons vriend is hy mos kastig, Walter Madeley,

Is nou baas oor die hele werkersklas.

Ja - Walter Madeley maak 'n Wet,

Om ons monde smeer hy vet.

Vaarwel vir demokrasie nou!]

These kind of lyrics served not only instruction in militant socialism, but a "romantic treatment of class-based identity" (Furey, $200 \mathrm{I}$, p. 56) contained in these songs helped workers reimagine their self-picture and replace the image of victims of an unjust system with that of agents and makers of their own future. The workers regained dignity when singing: 
O! do not bow and do not sway

To slavery or fascist law

We should all unite and stand together

Such low wages are no fun.

[O! Moenie buk nie, en moenie buig nie

Vir slawerny of fasiswet

Ons moet verenig, en almal saamspan

Sulke lae lone is geen pret.] (KW, March/April, I94I, p. I I)

\section{The Garment Workers' Drama}

The GWU was greatly inspired by the Soviet Union. The magazine frequently published articles expressing almost uncritical fascination with this country, aiming to familiarize the South African audience with Soviet trade unionism and at the time of WWII, to manifest the GWU's support for Soviet military efforts. Throughout the I930s, some key activists were sent on four week visits to the Soviet Union during which they, together with delegates from different countries, were shown a polished version of Soviet reality. On their return, the GW delegates published in the Garment Worker magazine elaborate reports where they painted idealized pictures of life in a utopian Soviet Union (e.g. reports by S. Venter or A. Scheepers in a couple of I939 issues): modern cities, clean factories, happy workers participating in party cultural events, etc. Furthermore, inspired by what they were shown during their stays, the activists set up a cultural section which organized literature discussion club, lectures on socialism, and theatre performances by and for factory workers. The amateur theatre group Eendrag/Unity led by Hester Cornelius was a project of the creation of a truly proletarian theatre, reminiscent of Soviet agitprop brigades of "self-styled educators" (compare Mally, 2000, p. Iо), which would deal with real working-class problems, offering an uprooted worker a new identification by becoming a socialist who fights for her rights and a better future (Cornelius in KW, May/ June, I94I).

Some plays were a reaction to actual events which took place in factories and can be viewed as documents of working-class history. The trial of the 22 (written between I936 and I94I) is an example of this sort drama: the plot was inspired by the 
hearing of Rose de Freitas and 2 I workers of Black \& Company in Cape Town, following illegal strikes in 1936 (Sachs, I957, p. 234). Reflecting the language of the work floor, the play contains passages both in Afrikaans, the language of the worker, and in English, the language of the capitalist. The play is also an attempt to propagate the idea of interracial solidarity among workers:

Why do you, a white girl, associate with these Blacks?" Sy antwoord: [She answers:]

"Yes, you try this one on me. (...) These coloured workers are no worse than I am, we are all slaves, and, (shouts) we don't want to be slaves any more!"

Most dramatic texts were not published and are preserved as unsigned and undated manuscripts in the archive of the William Cullen Library, Wits University in Johannesburg. The GW/KW periodical published shorter dramatical texts, agitprops in Afrikaans (Coetser, I 999, p. 62). These overtly didactic pieces had a form of a dialogue between two workers: the knowledgeable activist and the other one who was sceptical of trade unionism. In 'n Staaltiie uit die lewe van twee klerewerkers [An Episode from the Life of Two Garment Workers] (KW, Aug I939) by Mary Myburgh and Maud Goldwyer, Mary encourages Maud to join the trade union; in "Die Plig van Fabriekverteenwordiger" ["The Duty of Factory Representative"] (KW May/Jun I947) Bettie Botha explains to her colleague Sannie Smith the role of the trade union and how workers' representatives negotiate better working conditions with the factory board.

Works by the Cornelius sisters were created as proletarian drama with an unambiguous aim of awakening class consciousness in the audience. Johanna Cornelius's Eendrag [Unity] (undated) demonstrates the power of workers' mass actions against capitalism. The plot presents a story of Bessie, a worker who is unjustly dismissed. Yet the boss agrees to employ her again when other factory workers threaten to start a strike. Slavin van Suid-Afrika [Slave-Woman of South Africa] written jointly by the sisters (performed in I94I) presents three women workers who, after a tiring day of work, decide to voice their demands to the exploiting capitalists and demonstrate the socialist solidarity between the farmers and workers: land for poor landless farmers, higher wages 
and decent housing for workers. One of the workers, Anna, in calling other workers to join a protest march refers directly to the Afrikaner Voortrekker imagery: "Come follow in the footsteps of the Voortrekkerwomen (...). Co-workers let's come and organise a march of women and children through the streets of our city and demand a better life for every man, woman and child! ["Kom ons volg die voetstappe van die Voortrekkervrou (...) Medewerkers kom ons organiseer 'n optog van vrouens en kinders deur die strate van ons stad en ons eis 'n beter lewe vir elke man, vrou en kind!"].

Die Offerande, the longest Afrikaans drama published in its entirety in Klerewerker in 1942 also relies on Afrikaner cultural references which it shares with the middle-class farm novel but combines them with elements of socialist realism. The play contrasts the threatening city space with the farm and offers an array of characters representative of various role models. On the one hand, there are conservative figures who fear the change: Oom Kalie Potgieter, a typical Boer attached to his farm and Tant Anne who recalls women in concentration camps of the Anglo-Boer War. On the other hand, the play introduces Werda, a resolute socialist organizer and Dannie, a poor farmer's son turned factory worker and unionist.

Oom Kalie's daughter, Lettie, is the positive hero of the play and the story's plot reminds us of the Soviet socialist realist novel master plot. ${ }^{16}$ In the beginning, she shares her parents' traditional outlook and wants to spend her whole life on the farm where she was born, declaring: "Groenvlei [the farm] belongs to us. Our family was buried here; it's here that I've seen the light for the first time, and it's here where I'm going to breathe my last breath" ["Groenvlei behoort aan ons. Ons familie lê almal hier begrawe; Hier het ek die eerste lig aanskou en hier gaan ek my laaste asem uitblaas"] (Die Offerande, act I, p. 4). But then she meets Werda who guides her to political maturity as a class-conscious worker. The character of Lettie demonstrates the transition from political immaturity to political awareness and thus becomes a model for the reader to identify with. Moreover, as in a Soviet socialist realist propaganda fashion, the drama closes with an idealistic vision of a future South Africa where farmers and industrial 
workers harmoniously cooperate. This vision, as Werda claims, is the reality of the Soviet Union. After her last monologue, all actors join in a song expressing Afrikaner love for their land. Interestingly, the lyrics, starting with the words: "Uit die blou van onse hemel" ["From the blue of our heaven"], were written by C.J. Langenhoven, a well-known poet and a representative of the Afrikaner cultural elite. In this way, the Garment Workers, borrowing a poem from the mainstream middle-class literature, aimed to underline their complex modern identity: their being also an Afrikaner, not only a worker.

\section{Black Workers' Drama}

Black working-class theatre in South Africa started in 1979 as a result of a cooperation between the Junction Avenue Theatre and FOSATU (Federation of South African Trade Unions). The Junction Avenue Theatre, which came into being in 1976, was as an initiative of a group of politically engaged white students from the University of Witwatersrand who aimed to create scripts reflecting social and political problems, such as racism, injustice, and exploitation. FOSATU (I979-I985) was a nationwide organisation fostering cooperation between trade unions. This class-based organization with its programmatic non-racial "workerism," was also a force opposing apartheid in the early I980s (Byrne, Ulrich and Van der Walt, 20I7, p. 255). Yet, while the ANC based their struggle on the concept of nation as a territorial multi-class formation, the perspective of FOSATU centred on the class solidarity across racial divides, and saw the unions as part of a global working-class movement with distinct interests and goals of struggle against capitalism and apartheid, differing from those of the elites of any race (Byrne, Ulrich and Van der Walt, 20I7, pp. 26I-262). FOSATU and the Junction Avenue organized a series of workshops for Johannesburg industrial workers, which resulted in the creation of plays critically portraying the position of Black working-class in labour relationships. These first "workshop plays," "created and performed within the perimeter of working-class leisure time- and space” (Von Kotze, I 984, p. 92), were designed to transmit a call of class solidarity in a form intelligible to worker audiences, part of which was illiterate or semiliterate Black workers. 
The first outcome of the cooperation between white cultural workers and Black trade unionists was the play Security (I979) which depicted a man who, unable to find job, agrees to becoming a watchdog guarding a factory. The protagonist literally acts as a dog recieving a collar and a kennel and is trained by a middle-class clerk under the supervision his boss Mr Fatman. The play was performed in community halls and churches, usually on weekends, when working-class audience could attend (Von Kotze, I984, p. 93). Ilanga Lizophumelo Abasebenzi [The Sun Shall Rise for the Workers], focused on conflict within a factory and Dikhitsheneng [In the Kitchen], showed the exploitation of domestic workers. After these performances, Astrid von Kotze and Ari Sitas of the Junction Avenue Theatre were asked by the Metal and Allied Workers Union (MAWU) in Durban to assist in the creation of a workers' play there. The product of this cooperation was The Dunlop Play, whose premiere took place in April I983 at the annual meeting of the union (Orkin, I99I, p. I92). This performance was attended by about Iooo people and was well received (Von Kotze, I984, p. I06).

As Von Kotze reports, written scripts provided only suggestions for improvisation because illiterate and semi-literate worker-actors had to rely on memory. Therefore, the play's later versions contained various modifications, suiting occasions of performance (Von Kotze, I984, p. I07). Various degrees of literacy and the workers' knowledge of English had a big impact on the communication between the workers and the coordinators who assisted in writing the story line. The plot of The Dunlop Play presents a life of a worker from his entering employment at the Dunlop plant up until the present, at the same time illuminating the development of the MAWU as part of the labor movement history of South Africa. The challenges in the creation of the play lay also in the fact that the target audience, African workers, were not familiar with certain visual codes of European drama. For instance, to depict the history of the Dunlop trade union movement, the workshop coordinators resorted to the use of a "cranky" (Von Kotze, I984, pp. I00-IOI), a device popular with the I960s and I970s agitprop groups. The device fulfilled the role of a movie screen and consisted of a roll of paper or canvas with painted images, which was placed in a large frame. Slow unwinding of the roll served 
to present lapses of time in a way comprehensible to African audience.

The play recreated events workers could recognize and identify with, such as discussions about the trade unions, doubts concerning union membership. It also contained lighter notes, such as the parody of bosses and supervisors by means of miming and putting on masks, providing comic relief to the plot. Von Kotze stresses the didactic aspect of the workshops, the role which they played in community building and in the creation of working-class awareness. She cites the words of a couple of participants who claim that discussing problems, choosing episodes and designing scenes to be performed, they discovered the sense of common goal, solidarity, and agency (Von Kotze, I984, p. I09).

Typically, and to a much greater extent than in the case of the white Garment Workers plays, Black workshop plays incorporated songs which served as an introduction and commentary to improvised speeches given by actors. Some songs, employing the call-and-response technique, invited the participation of the audience, reinforcing class solidarity. The inclusion of songs and dance-routines within the plays made drama a more accessible form to an audience not familiar with theatre, whose contact with European culture was mostly conducted through church and mission schools. Even though co-ordinators relied on European models of theatre, the plays which resulted from workshops according to Von Kotze (I984, p. I Io) - enabled workers to find their own ways to incorporate performative aspects (miming, singing, dancing) of their culture which are constituent of their oral storytelling tradition.

\section{Working-Class Identity in Zulu Choral Music}

Even though Black working-class theatre came into being quite late, other forms serving expression of Black working-class identity had emerged much earlier. Such forms were songs, some of which were later incorporated into theatrical performances. Songs, chants, traditional poetry mixing the word and music are oral forms that need to be taken into account when approaching the concept of literature in South Africa. It comes as no surprise 
that these were the local forms that spontaneously came to reflect the changing identity of Black migrant workers in the industrial centres of Johannesburg and Durban. Male Zulu choral music, so-called isicathamiya (see Erlmann, I987), is a truly hybrid genre, incorporating old tribal forms of consciousness, pan-African ideology, Zulu nationalism and the emerging Black working-class consciousness.

The history of the genre dates back to the late $19^{\text {th }}$ century and the popularity of traveling American minstrel shows in South Africa (Erlmann, I987, p. 5). Its most dynamic development, however, took place in the I920s and I930s during the most rapid industrialisation and intensified migration of Black workers to the cities. It was also when the mission-educated Reuben T. Caluza bridged the gap between American minstrels' style and the then popular ragtime (Erlmann, I987, p. 7), and wrote songs about hardships workers suffer due to racism on the job. Throughout the I930s, many bands, such as the Bantu Glee Singers or The Crocodiles, to name just a few, developed Caluza's style. Musically, isicathamiya was a product of experimentation of several generations of migrant workers and an amalgam of styles: an adaptation of traditional Zulu wedding songs, Afro-American religious hymns, and western rock and roll.

The hybridity of this genre's musical dimension corresponds with the hybridity of the new urban Black identity it served. Lyrics told stories from the perspective of young men living isolated in factory hostels and separated from families. The songs expressed rural nostalgia juxtaposed with descriptions of the evils of the city, violence and alcohol, an element common in all abovementioned literature of new urban communities, regardless of race. But at the same time the texts accentuated the pride at being an urban citizen, in this way conveying a constructive message: the urban Black person needs to embrace his new identity, because it gives him also the strength to resist oppression, both economic and racial (Erlmann, I987, p. 4). The genres manifested the ideals of trade unionism, among others. For example, throughout the I920s music ensembles organizing workers' leisure time, were active among workers of Dunlop in Durban, and had links with the ICU (Industrial and Commercial Workers, a trade union 
established in I919 by Clements Kadalie) until the union's disintegration in the early I930s.

The popularity of the style did not diminish throughout the I 940 s and I950s. A good example is the song "Yethul' Isiggoko" [Take off your hat] by S. Linda's Evening Birds, which was frequently broadcast by a Durban workers' radio station between I 943 and I948:

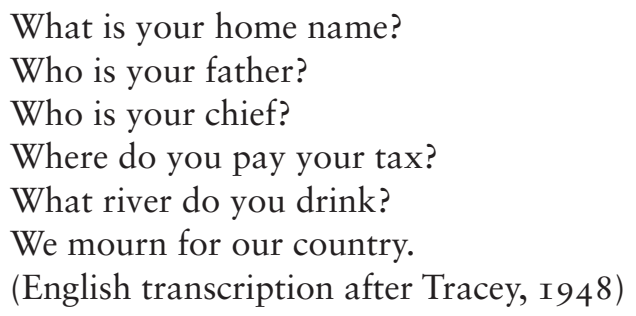

This song addresses the new complex identity of the urban Black and enumerates components of his hybrid identity referring to his family left in the countryside, to his place in the tribal hierarchy, and to his being a tax-paying citizen. The line "We mourn for our country" can be read as a nostalgic call to the lost past, but also as a protest against the situation in which segregationist legislation deprived Black population of their rights - Black citizens lament the country which has been taken away from them.

\section{Worker Praise Poetry}

In the I980s, the isicathamiya musical style was sometimes combined with izibongo, Zulu praise poetry. For example, The K-Team ensemble, consisting of the Kellogs' factory workers, performed a song in which they manifested their support for FOSATU leaders:

Let us thank FOSATU for representing the Black nation.

We thank you Dlami and Maseko and people who help you.

Even if it is tough, we will grab the hot iron

We will persevere till the end. (after Siyabona Fosatu, Shifty

Records, Fosatu Worker Choirs, L4.)

Similarly to songs, the izibongo was an essential part of the Zulu oral literary tradition. Such working-class poets as Mi S'dumo Hlatshwayo (born I95I) and Alfred Temba Qabula (I942-2002), 
among others, who were also involved in the production of The Dunlop Play (Orkin, I991, p. I92), turned the izibongo into a working-class form of expression. Michael Chapman (I999) argues that the Zulu praise poetry represents a "useable past," since its important quality is malleability: it can be adapted to various circumstances (Chapman, I999, p. 34). Therefore, its workingclass variant links the economic situation of Black workers to the history and culture of this people. Praise poems were originally devoted to mighty Zulu kings and glorified military power and warrior ethos. Their performative character created bonds among community members and gave expression to their feelings of anger, joy, or grief (Chapman, I999, pp. 35-36). As a form of artistic expression, it "bred and nurtured" amongst "ordinary people" (Sole, I994, p. 2) and was evolving throughout time, reflecting the history of those people. Already influenced by Christian sermons and gospel singing, in the r980s it thematized the working-class experience, which can be seen as a following step in the hybridization which had always characterized this form.

The worker imbongi (poets), drawing from the old oral tradition, oscillated between "the heroic and the ordinary in an attempt to locate and articulate their identity as an exploited working-class in South Africa” (Mashige, 2006, p. I44). Initially not recognized as artists by South African elite, they offered a democratic art, preforming in trade unions' mass events, such as rallies or funerals of political activists, becoming indispensable at such occasions. It needs to be emphasized that these artists were Black class-conscious poets who performed as representatives of proletariat, addressing Black workers by means of literature accessible even to those whose literacy was very basic. Thematizing the struggle for workers' rights, they fought for the emancipation of the oppressed majority of South Africans (Mashige, 2006, p. I46).

Mi S'dumo Hlatshwayo and Alfred Temba Qabula were members of the Metal and Allied Workers Union. Hailing from poor working-class backgrounds, they believed that poetry is public property and should not be reserved to the intellectual elite. Together with other working-class imbongi they published their poems in two collections: Black Mamba Rising: South African Worker Poets in Struggle (1986) and Izinsingisi: Loud Hailer Lives, South African Poetry from Natal (1988). Ari Sitas of the 
Junction Avenue Theatre, who wrote the introduction to the latter collection, noted the syncretism of this poetry and observed that the reader can find references to "the Nguni oral tradition, the Christian Bible, the black-consciousness poetry of the I970's, jazz poetry just as [one] can pick the rhythms and imagery of street talk" (Sitas, I988, p. ii). Considering that praise poetry originated as an oral form, a performance which was linked to a particular event, the fact of writing praise poems down is also the hybridizing impact of a European convention.

Mashige (2006) describes the izibongo tradition as intricate, with its unique poetic devices, such as imagery, symbolism, satire, and parallelism (2006, p. I45). Unlike traditional praise poetry, "Praise Poem to FOSATU" by Alfred Temba Qabula was initially composed on paper in the early I980s and delivered in Khosa/ Zulu at workers' rallies. In this genuinely hybrid form, the trade union is addressed as the protector of workers in the style chieftains used to be addressed in the izibongo of the past. The poem contains a number of apostrophes where FOSATU is personified: it is "the moving forest of Africa," "the hen with wide wings that protects its chickens," "the lion that roared in Pretoria North." The poem connects the past with the present and the spiritual with the material, referring to the ancestors and economic situation of the workers: "Mvelinqangi and the ancestors have answered us, and sent to us FOSATU! (...). Teach us FOSATU about the past organizations before we came." (FOSATU Worker News, August I984, p. I2).

Hlatshwayo's “The Black Mamba Rises” acknowledges working-class history: this poem praises the protests of Dunlop factory workers. The poem employs the animal symbolism which is typical of the izibongo tradition. The Black mamba is a symbol of the rise and revival of the Black workers' trade union movement against apartheid and exploitation: the movement seems dead after blows it has received but like the snake being severely hit and deemed dead, it is alive and only gathers strength to strike:

Never again shall it move,

Never again shall it revive,

Never again shall it return,

Yet it was beginning to tower with rage. (Black Mamba, p. 25) 
The buffalo is another powerful animal to which the workers' movement is compared. This image is juxtaposed with the "tragicomic nomenclature" (Mashige, 2006, p. I5I) of apartheid: the verbal manifestation of violence which imposed on Black people random identities. This piece also records the changing lot of Black South Africans:

You black buffalo

black yet with tasty meat

The buffalo that turns the

Foreigners' language into

Confusion.

Today you're called a Bantu,

Tomorrow you're called a Communist

Sometimes you're called a Native.

Today again you're called a Foreigner,

Today again you're called a Terrorist,

Sometimes you're called a Plural,

Sometimes you're called an

Urban PURS [Permanent Urban Residents].

(Black Mamba, p. 27)

Other poems in the collections are a call to unity of workers and wish of peace as such as Hlatshwayo's "We Workers Are a Worried Lot" (Black Mamba, I986, p. 32) or “Workers' Lamentation for Ancient Africa" are a protest against white men exploiting Africa, disowning the county's Black people:

Hungry lambs

In an Africa of shrubs

Craving for shelter

To protect us from assailing storms

In an Africa

Of caves and eroded gorges (Black Mamba, p. 29)

When addressing issues of class and race, the poet uses Biblical imagery: victims of exploitation, the workers are depicted as hungry innocent lambs, looking for protection. Workers' izibongo is essentially a hybrid form, incorporating Christian vocabulary and teachings because of its authors' exposure to and assimilation of Christianity - an ideology initially alien to them that was brought by whites. 
Here, one encounters references to the romantic nostalgia for a mythical Africa. This motif is characteristic for all workingclass literature discussed in this contribution - only the source of displaced people's misery is variously defined. In Afrikaans novels and plays depicting the poor whites' situation, British capitalists are, most of all, to blame. Texts describing the lot of Black workers in the "Jim goes to Joburg" convention, written from the middle-class outsider perspective - both by white and Black observers-socialists - always pointed that capitalism in South Africa cannot be separated from its racial aspect. The capitalist represents the colonial power of the white man over Africa, and this power is a destructive intrusion in the life of African communities. The Black oral poetry, created by workingclass members, also levels criticism at European countries but underlines that their intrusion in Africa has destroyed not only the agrarian society but also African humanism and dignity (Mashige, 200I, p. 8). Therefore, workers' izibongo played an important part as an expression of a recreated dignity of the Black worker who protests against economic exploitation and racial discrimination.

\section{Conclusion}

This aim of this overview was to cast some light on the hybrid nature of the concept of South African working-class literature. Considering the multiplicity of forms this literature involves, hybridity seems to be the most prominent unifying quality allowing to capture such diverse texts under one umbrella term of "South African working-class literature." This concept includes works created in various languages, by authors of various ethnicities, from insider and outsider perspectives expressing diverse goals and, finally, having various target audiences. All those texts formed a reaction to industrialization which has dramatically transformed traditional - that is pastoral, rural - Black and white communities of South Africa into urban modern society. Therefore, the recurrent nostalgia for the lost idyllic past invariably appears in texts thematizing the painful encounter of the agrarian population with the destructive capitalism of the city. This theme can be found in English realistic prose telling the "Jim goes to Joburg" 
story, in Afrikaans writings about the poor whites' issue, in the creative output of the Garment Workers, and in Black workers' praise poetry of the I 980 .

Moreover, South African working-class literature, documenting the experience of working people can be approached as histoire croisée. It crosses in its development the histories of labor migrations within the South of Africa, histories of British intellectuals commenting on South African economic, political and social situation, history of Afrikaner nationalism, and history of emancipation and freedom struggle against the apartheid regime. In the creation of working-class literary forms, both foreign and local discourses, traditions, and forms of artistic expression have merged. Foreign elements included for example the novel form applied to the experience and sensibility of Africans or Soviet socialist realism in La Guma's English novels and in Afrikaans drama by the Garment Workers. Also, traditional forms, such as Zulu oral praise poetry or Afrikaans folk songs were adapted to carry socialist message, and to reinforce the feeling of solidarity among workers. The working-class identity, as manifested in literature, was therefore built not in opposition to local identities but relied on the continuity with a whole range of local traditions.

\section{Endnotes}

I. Compare e.g. Nilsson and Lennon, 2016.

2. See discussion by Clarke in vol. I, 2017.

3. Compare Willemse in Van Coller, I999; Chapman, 2003; Attwell and Attridge, $20 \mathrm{I} 2$.

4. For example Ulrich, 2002; Van Holdt, 2002; Buhlungu, 2006; Bendix, 20Iо; Bezuidehout \& Buhlungu, 20II, to mention only a few publications.

5. Witz, I988; Brink, I989; Berger, I992; Hyslop, I999, and more recent studies, e.g. Lange, 2003 or Kenefick, 2010 , are less numerous.

6. See Alex La Guma in discussions by Mkhize I998, 20 I0.

7. See Brink, I987, Lourens, I997, Coetser, I999, and Vincent, 2000. 
8. See Werner and Zimmerman, 2006.

9. Compare Krebs, I997, p. 428.

IO. See the discussion on Schreiner's "glocal" perspective by Stanley, Dampier and Salter, 20I0.

I I. See Lukacs, I963, p. I9.

I 2. Nowadays, the term "kaffir" is conceived of as very offensive. At the beginning of the 2oth century and before, however, it was used by whites to denote a Black person and was acceptable in press. See "The Safeguard of Kaffir Socialism" I908, p. 448.

I3. See Mkhize, I998, p. 24.

I4. The term "colored" (also spelled "coloured" in British English) in South Africa customarily refers to a person of mixed origin (European and African, Malayan, Khoisan etc.) and as such distinct from a Black person (a Bantu, i.e. a Zulu, Xhosa etc.). Due to its being the first European settlement in South Africa, Cape Town became a place of contact and a melting pot of ethnicities, and until today has the most numerous population of people described as coloreds. The formally defined and legally sanctioned distinction between Blacks and coloreds dates back to the apartheid area when South African society was divided (in many cases arbitrarily) into four categories: Whites, Blacks, Indians, and Coloreds. For more on the complexity of "coloured identities" see Mohamed Adhikari (2009), Burdened by Race. Coloured Identities in Southern Africa. Cape Town: Juta and Company. The term has long functioned as fairly neutral in South African academic discourse, however, recently it started to be perceived as offensive in certain contexts, while some people still voluntarily identify themselves as coloreds; see discussion in South African press, e.g.: Tom Head, "Tony Ehrenreich says 'coloured' is derogatory, should be replaced by 'camisa"'. The South African, 20 Sept 2018 (https://www.thesouthafrican.com/news/tony -ehrenreich-coloured-camisa/), or "Calls for the term 'Coloured' to be abolished", eNCA, 7 Oct 2018 (https://www.enca.com/news /calls-term-coloured-be-abolished).

I 5. All translations from Afrikaans by the author of the contribution.

I6. Compare Clark, 2000. See a more extensive discussion of Die Offerande in Drwal 2020. 


\section{References}

Abrahams, P. (1946). Mine Boy. London, D. Crisp.

Adhikari, M. (2009). Burdened by Race. Coloured Identities in Southern Africa. Cape Town, Juta and Co.

Attwell, D, and Attridge, D. (2OI 2). The Cambridge History of South African Literature. Cape Town, Cambridge University Press.

Bendix, S. (2010). Industrial Relations in South Africa. Cape Town, Juta \& Co.

Berger, I. (I992). Threads of Solidarity. Women in South African Industry, 1900-1980. Bloomington, Indiana University Press.

Bezuidenhout, A. \& Buhlungu, S. (20II). "From Compounded to Fragmented Labour. Mineworkers and the Demise of Compounds in South Africa." Antipode, 43 (2), pp. 237-263. DOI: https://doi .org/IO.I I I I/j.I467-8330.20I0.00758.x

Blackburn, D. (1908). Leaven. A Black and White Story. London, Rivers.

Blackburn, D. (I908). "The Safeguard of Kaffir Socialism.” The New Age, 3 (23), p. 448.

"Bobbejaan klim die berg” (I94I). Klerewerker, March/April, p. I I.

Bonner, P, Hyslop, J. \& Van Der Walt, L. (2007). “Rethinking Worlds of Labour. Southern African Labour History in International Context." African Studies, 66 (2/3), pp. I37-I67. DOI: https://doi .org/IO.I080/000201 80701482628

Boonzaier, F. W. (I93 I). Die Stad Sodom. Kaapstad, HAUM.

Brink, E. (I 987). "Maar 'n Klomp 'factory' Meide. The Role of the Female Garment Workers in the Clothing Industry, Afrikaner Family and Community on the Witwatersrand During the I920s." In B. Bozzoli, ed. Class, Community, and Conflict: South African Perspectives. Johannesburg, Ravan Press, pp. I77-208.

Brink, E. (1989). "Purposeful Plays, Prose and Poems: The Writings of the Garment Workers, I929-1945." In C. Clayton, ed. Woman and Writing in South Africa. Marshalltown, Heinemann, pp. I07-I 27.

Buhlungu, S. (2006). "Rebels without a Cause of Their Own? The Contradictory Location of White Officials in Black Unions in 
South Africa, I973-94." Current Sociology 54 (3), pp. 427-45I. DOI: https://doi.org/IO.II77/00II392106063I9I

Burke, P. (2009). Cultural Hybridity. Cambridge, Polity.

Byrne, S., Ulrich, N. \& van der Walt, L. (2017). "Red, Black and Gold. FOSATU, South African 'Workerism', 'Syndicalism' and the Nation”. In E. Webster \& K. Pampillas, eds. The Unresolved National Question in South Africa. Left Thinking Under Apartheid. Johannesburg, Wits University Press, pp. 254-273.

Chapman, M. (I999). "From Shaka's Court to the Trade Union Rally. Praises in a Usable Past." Research in African Literatures, 30 (I), pp. 34-43. https://www.jstor.org/stable/382047 I

Chapman, M. (2003). South African Literatures. Pietermaritzburg, University of Natal Press.

Clark, K. (2000). The Soviet Novel. History as Ritual. Bloomington, Indiana University Press.

Clark, K. (20I7). "Working-Class Literature and/or Proletarian Literature. Polemics of the Russian and Soviet Literary Left." In J. Lennon \& M. Nilsson, eds. Working-Class Literature(s). Historical and International Perspectives, Stockholm, Stockholm University Press, pp. I-30. DOI: https://doi.org/Io.I6993 /bam.b

Coetser, J. L. (I999). "KWU-werkersklasdramas in Afrikaans (ca. 1930 - ca. 1950)." Literator, 20 (2), pp. 59-75.

Cornelius, H. (I942). "Die Offerande.” Klerewerker July/August, pp. 3-5, and Klerewerker November/December, pp. 3-6.

Cornelius, H. (I94I). “Eendrag teater.” Klerewerker, May/June, p. II.

Cornelius J. Eendrag. Unpublished play, University of the Witwatersrand, Johannesburg, William Cullen Library, Records of the Garment Workers Union AHıо92, Bcd I.2.

Cornelius, J. \& Cornelius, H. Slavin van Suid-Afrika. Unpublished drama, University of the Witwatersrand, Johannesburg, William Cullen Library, Records of the Garment Workers Union AHı092, Bcd I.2., I94I.

Dhlomo, R. R. R. (I93I). An African Tragedy. Lovedale Press. 
Drwal, M. (2020). "Afrikaans Working-Class Drama in the Early I940s. Socialist Realism in Die Offerande by Hester Cornelius." Dutch Crossing [online]. DOI: https://doi.org/IO.I080/03096564 $.2020 .172386 \mathrm{I}$

Erlmann, V. (1987). "Singing Brings Joy to the Distressed. Social History of Zulu Migrant Worker's Choral Competitions." University of the Witwatersrand History Workshop.

Furey, H. L. (200I). "IWW Songs as Modernist Poetry". The Journal of the Midwest Modern Language Association, 34 (2), pp. 5 I-72. DOI: https://doi.org/I0.2307/I 3 I 5 I 40

Gaylard, R. (2005). "R.R.R. Dhlomo and the Early Black South African Short Story in English." Current Writing. Text and Reception in Southern Africa, I7 (I), pp. 52-69. DOI: https://doi.org/Io.Io80 /IOI3929X.2005.9678206

Gray, S. (I985). "Third World meets first World. The Theme of 'Jim Comes to Joburg' in South African English Fiction.” Kunapipi, 7 (I), pp. 6I-8o. http://ro.uow.edu.au/kunapipi/vol7/issi/9

Hanekom, A. J. (1938). Die Skeidsmuur. Kaapstad, Nasionale Pers.

Hoogenhout, I. ( (1925). Op die delwerye. Vyf sketse nit die lewe. Cape Town, M. Miller.

Jones, M. (2012). "Urbanism and Black Mobility in Peter Abrahams's Mine Boy." Journal of Southern African Studies, 38 ( I), pp. 203-2 I 5. DOI: https://doi.org/IO. I080/03057070.20I I.639206

Hyslop, J. (I999). "The Imperial Working Class Makes Itself 'White'. White Labourism in Britain, Australia, and South Africa Before the First World War." Journal of Historical Sociology, I 2, pp. 398-42 I. DOI: https://doi.org/IO.I I I I/I 467-6443.00098

Kenefick, W. (2010). "Confronting White Labourism. Socialism, Syndicalism, and the Role of the Scottish Radical Left in South Africa before I9 4." International Review of Social History, 55 (I), pp. 29-62. DOI: https://doi.org/IO.IOI7/So0208590099906I7

Krebs, P. M. (1999). Gender, Race, and the Writing of Empire. Cambridge, Cambridge University Press.

Krebs, P. M. (1997). “Olive Schreiner's Racialization of South Africa." Victorian Studies, 40 (3), pp. 427-444. https://www.jstor .org/stable/3829293 
La Guma, A. (I99I). “To Literary Gazette.” In C. Abrahams, ed. Memories of Home: The Writings of Alex La Guma. New Jersey, Africa World Press.

La Guma, A. (1967). A Walk in the Night and Other Stories. London, Heinemann.

La Guma, A. (1964). And a Threefold Cord. Berlin, Seven Sees Publishers.

La Guma, A. (1967). The Stone Country. London, Heinemann.

La Guma, A. (1972). In the Fog of Season's End. London, Heinemann.

Lange, L. (2003). White, Poor and Angry. White Working-Class Families in Johannesburg. London, Routledge.

Lichtenstein, A. (2004). "The Hope for White and Black'? Race, Labour and the State in South Africa and The United States, I924I956." Journal of Southern African Studies, 30 (I), pp. I33-I 53. DOI: https://doi.org/IO.I080/0305707042000223979

Lourens, A. (I997). "Polemiek en kanon: kanonisering van die vroulike outeur in die Afrikaanse prosa van die dertiger- tot die negentigerjare.” Pretoria University (Unpublished MA thesis).

Lub, J. ( I930). Eenvoudige mense. Cape Town, H.A.U.M.

Lukacs, G. (1963). The Meaning of Contemporary Realism. London, Merlin Press.

Mally, L. (2000). Revolutionary Acts. Amateur Theater and the Soviet State, I9I7-I938. Ithaca/London, Cornell University Press.

Mashige, M. (200I). Mi Hlatshwayo and Temba Qabula. Worker Poets in the Struggle Against Apartheid. Thohoyandou: University of Venda for Science and Technology.

Mashige, M. (2006). "Identity and culture in Mi S'dumo Hlatshwayo's worker poetry." Tydskrif vir Letterkunde, 43 (2), pp. I4I-I60. DOI: https://doi.org/I0.43 I4/tvl.v43i2.2975 I

Masilela, N. (2004). "Peter Abrahams in the Modern African World." Current Writing, I6 (2), pp. 3 I-46. DOI: https://doi.org/IO.Io80 /IOI3929X.2004.9678I93

Meyer, M. (I94I). "De plig van de vrou," Klerewerker, March/April, p. 3 . 
Mkhize, J. (1998). Social Realism in Alex La Guma's Longer Fiction. University of Natal (Unpublished PhD thesis).

Mkhize, J. (2010). "Shades of Working-Class Writing. Realism and the Intertextual in La Guma's In the Fog of the Seasons' End." Journal of Southern African Studies, 36 (4), pp. 9I3-922. DOI: https://doi.org/I0.1080/03057070.2010.527644

Muller, I. (I940). “Die baksteen.” Klerewerker. June/July, pp. 3-4.

Myburg, M. \& Goldwyer, M. (I939). "'n Staaltjie uit die Lewe van Twee klerewerksters." Klerewerker, August, pp. 8-9.

Nilsson, M. \& Lennon, J. (20I6). “Defining Working-Class Literature(s). A Comparative Approach Between U.S. Working-Class Studies and Swedish Literary History.” New Proposals. Journal of Marxism and Interdisciplinary Inquiry, 8 (2), pp. 39-6I.

Nkosi, L. (1975). The Transplanted Heart. Essays on South Africa. Benin City, Ethiope Publishing Corporation.

Orkin, M. (I99I). Drama and the South African State. Manchester, Manchester University Press.

"Our Policy.” (I936). Garment Worker, October, p. I.

Pienaar, V. (2003). Jo'burg, die blues en 'n Ford Thunderbird. Kaapstad, Kwela Books.

Plomer, W. (1927). I Speak of Africa. London, Tavistock.

Qabula, A. T. (1984). "Praise Poem to FOSATU”. FOSATU Worker News, August, p. I 2.

“Rype Ondervinding.” (I940). Klerewerker, Febrary, p. I4.

Sachs, E. S. (1957). Rebel daughters. London, MacGibbon \& Kee.

Scheepers, A. (1939). “My Reis Oorsee.” Klerewerker, January, pp. 3, 5, I $2-I 3$.

Schreiner, O. (1909). Closer Union. Cape Town, Constitutional Reform Association.

Schreiner, O. (I9I I). Women and Labour. London, Fisher Unwin.

Shum, M. (I994). "The Content of the Form: Romance and Realism in Douglas Blackburn's 'Leaven." English in Africa, $2 \mathrm{I}$ ( $\mathrm{I} / 2)$, pp. 93-IO2. https://www.jstor.org/stable/40238725 
Schumann, P. W. S. (I933). Hantie kom huis-toe. Pretoria, J.L. van Schaik.

Scully, W. C. (1923). Daniel Vananda. The Story of a Human Being. Cape Town, Juta \& Co.

Sitas, A. ed. (1986). Black Mamba Rising. South African Worker Poets in Struggle. Durban, Culture and Working Life Publication.

Sole, K. ( I994). "Democratising Culture and Literature in a 'New South Africa.' Organisation and Theory.” Current Writing, 6 (2), pp. I-37.

Stanley, L, Dampier, H. and Salter, A. (20I0). "Olive Schreiner Globalising Social Inquiry. A Feminist Analytics of Globalisation." The Sociological Review, 58 (4), pp. 657-680. DOI: https://doi .org/IO.I I I I/j.I467-954X.20I0.0I945.X

Tracey, H. (1948). Lalela Zulu. Ioo Zulu Lyrics. Johannesburg, African Music Society.

The Trial of the 22: A One Act Play in Three Scenes. William Cullen Library, University of the Witwatersrand, AHıo92/Cba 2.4.2.

Ulrich, N. (2002). Only the Workers Can Fee the Workers. The Origin of the Workers' Control Tradition and the Trade Union Advisory Committee (TUACC), I970-I979. University of Witwatersrand (MA dissertation).

Van Bruggen, J. (1924). Ampie I. Die natuurkind. Amsterdam, Swets en Zeitlinger.

Van Bruggen, J. (1928). Ampie II. Die meisiekind. Amsterdam, Swets en Zeitlinger.

Van Bruggen, J. (1942). Ampie III. Die kind. Kaapstad, Nasionale Pers.

Van Coller, H. P. (2008). "The Peregrination of Afrikaans Prose Fiction from Farm to City." Journal of the Australasian Universities Language and Literature Association, I09, pp. 27-46. DOI: https:// doi.org/IO.I I 79/000I 27908805259879

Van der Berg, W. (I946). Reisigers na nêrens. Kaapstad/Bloemfontein/ Port Elizabeth, Nasionale Pers.

Van der Berg, W. (I947). Tema en variasies. Kaapstad/Bloemfontein/ Port Elizabeth, Nasionale Pers. 
Van den Heever, C. M. (I959). Versamelde Werke, VI. Johannesburg, Afrikaanse Pers.

Van der Walt, L. (2007). "The First Globalisation and Transnational Labour Activism in Southern Africa. White Labourism, the IWW, and the ICU, I904-I934." African Studies, 66 (2-3), pp. 223-25 I. DOI: https://doi.org/IO.I080/00020I 8070I4827I9

Van Jaarsveld, F. A. (1982). Die Afrikaner se Groot Trek na die Stede en Ander Opstelle I886-1976. Johannesburg, Perskor, pp. I35-225.

Van Niekerk, J. (20 I I). "Verstedeliking, Suid-Afrikaanse letterkundes en die kultuurteks." Tydskrif vir Letterkunde, 48 (2), pp. 50-70. DOI: https://doi.org/IO.43 I4/tvl.v48i2.68303

Van Wyk, J. (I990) "Nationalist Ideology and Social Concerns in Afrikaans Drama in the Period I930-I940." University of the Witwatersrand, Johannesburg. Structure and Experience in the Making of Apartheid, 6-Io February I990.

Van Wyk Louw, N. P. (1939). Berigte te velde: opstelle oor die idee van 'n Afrikaanse nasionale letterkunde. Pretoria, Van Schaik.

Venter, E. A. (1933). Drankwet. Kaapstad, HAUM.

Venter, S. (I939). "Die Lewe van Klerewerkers in die U.S.S.R." Klerewerker, March, pp. 7-8, I 2.

Verwey, E. J. (1995). New Dictionary of South African Biography, vol. I. Pretoria, HSRC Publishers.

Vincent, L. (2000). "Bread and Honour: White Working Class Women and Afrikaner Nationalism in the r930s." Journal of Southern African Studies, 26 (I), pp. 6I-78. DOI: https://doi.org /I0.1080/030570700I08388

Von Holdt, K. (2002). "Social Movement Unionism. The Case of South Africa." Work, Employment and Society, I6 (2), pp. 283304. DOI: https://doi.org/IO.I I 77/09500I702400426848

Von Kotze, A. (1984). “Workshop Plays as Worker Education.” South African Labour Bulletin, 9 (8), pp. 92-I I I.

Wade, M. (I972). Peter Abrahams. London, Evans.

“Wat maak oom Kalie daar." (I94I). Klerewerker, May/June, p. 7. 
Werner, M. \& Zimmerman, B. (2006). "Beyond Comparison. Histoire Croisée and the Challenge of Reflexivity." History and Theory, 45, February, pp. 30-50. https://www.jstor.org/stable/3590723

Willemse, H. (I999). “'n Inleiding tot buite-kanonieke Afrikaanse kulturele praktyke.” In H. P. van Coller (ed.) Perspektief en Profiel. 'n Afrikaanse Literatuurgeskiedenis. Vol. 2, pp. 3-20.

Witz, L. (1988). "Separation for Unity. The Garment Workers Union and the South African Clothing Workers Union I928 to I936." Social Dynamics, I4 (I), pp. 34-45. 